\title{
Pengaruh Kemampuan Pemahaman Konsep Matematika dan Kemampuan Numerik Terhadap Kemampuan Menyelesaikan Soal Cerita
}

\author{
Zulia Hartini ${ }^{1, \text { a) }}$, Syahrul Azmi ${ }^{2, b)}$, Dwi Novitasari ${ }^{3, \text { c) }}$, Nani Kurniati ${ }^{4, \text { d) }}$ \\ ${ }^{1}$ Mahasiswa Universitas Mataram, Mataram, Nusa Tenggara Barat \\ ${ }^{23,4}$ Dosen Universitas Mataram, Mataram, Nusa Tenggara Barat \\ Email penulis: ${ }^{\text {a) }}$ zuliahartini3@gmail.com, ${ }^{\text {b) }}$ syahrulazmi.fkip@gmail.com, ${ }^{\text {c) }}$ dwinovitasari@unram.ac.id, \\ d)naniasyari@gmail.com
}

\begin{abstract}
This study aims to determine the effect of the ability to understand mathematical concepts and numerical abilities on the ability to solve story problems. The study is ex-post facto with a quantitative approach. The population in this study was class VIII SMP Negeri 1 Kopang. The number of samples as many as 36 students were taken by simple random sampling technique. The data collection technique is in the form of a test. The data obtained were analyzed using a prerequisite test analysis, namely normality test, linearity test, multicollinearity test and heteroscedastic test then continued with hypothesis testing, namely simple and multiple linear regression analysis. The results of data analysis show: 1) the level of relationship between the ability to understand mathematical concepts and students' ability to solve story problems is in the very strong category because the correlation coefficient is 0.844 and there is a significant positive effect with a contribution of $71.2 \%$; 2 ) the level of relationship between numerical ability and students' ability to solve story problems is in the strong category because the correlation coefficient is 0.726 and there is a significant positive effect with a contribution of $52.6 \%$; 3) the level of relationship between the ability to understand mathematical concepts and numerical abilities with students' ability to solve story problems is in the very strong category because the correlation coefficient is 0.869 and there is a significant positive effect with a contribution of $75.6 \%$.
\end{abstract}

Keywords: ability to understand mathematical concepts, numerical ability, ability to solve story problems

\begin{abstract}
Abstrak
Penelitian ini bertujuan untuk mengetahui pengaruh kemampuan pemahaman konsep matematika dan kemampuan numerik terhadap kemampuan menyelesaikan soal cerita materi pola bilangan. Jenis penelitian ini adalah ex-post facto dengan pendekatan kuantitatif. Populasi dalam penelitian ini adalah siswa kelas VIII SMP Negeri 1 Kopang. Jumlah sampel sebanyak 36 siswa yang diambil dengan teknik simple random sampling. Adapun teknik pengambilan data berupa tes. Data yang diperoleh dianalisis menggunakan analisis uji prayarat yaitu uji normalitas, uji linieritas, uji multikolinieritas dan uji heteroskedastisitas kemudian dilanjutkan dengan uji hipotesis yaitu analisis regresi linier sederhana dan berganda. Hasil analisis data menunjukkan: 1) tingkat hubungan antara kemampuan pemahaman konsep matematika dengan kemampuan siswa dalam menyelesaikan soal cerita berada dalam kategori sangat kuat dengan koefisien korelasinya sebesar 0,844 dan terdapat pengaruh yang positif signifikan dengan kontribusi sebesar $71,2 \%$; 2) tingkat hubungan antara kemampuan numerik dengan kemampuan siswa dalam menyelesaikan soal cerita berada dalam kategori kuat dengan koefisien korelasinya sebesar 0,726 dan terdapat pengaruh yang positif signifikan dengan kontribusi sebesar $52,6 \%$; 3) tingkat hubungan antara kemampuan pemahaman konsep matematika dan kemampuan numerik dengan kemampuan siswa dalam menyelesaikan soal cerita berada dalam kategori sangat kuat dengan koefisien korelasinya sebesar 0,869 dan terdapat pengaruh yang positif signifikan dengan kontribusi sebesar $75,6 \%$.
\end{abstract}

Kata kunci: kemampuan pemahaman konsep matematika, kemampuan numerik, kemampuan menyelesaikan soal cerita

Copyright (c) 2021 Hartini, Azmi, Novitasari, Kurniati

$\triangle$ Corresponding author:

Email Address: zuliahartini3@gmail.com

Received 20 Januari 2022, Accepted 23 Februari 2022, Published 24 Februari 2022

https://doi.org/10.21009/irpmj.v4i1.23022 


\section{PENDAHULUAN}

Menurut Depdiknas (2006: 345), mata pelajaran matematika perlu diberikan kepada semua siswa mulai dari sekolah dasar untuk membekali siswa dengan kemampuan berpikir logis, analitis, sistematis, kritis dan kreatif serta kemampuan bekerjasama siswa. Adapun tujuan pembelajaran matematika di SMP tercantum dalam Permendiknas No.22 Tahun 2006 tentang Standar Isi, agar peserta didik memiliki kemampuan berikut: a) memahami konsep matematika, menjelaskan keterkaitan antar konsep atu logaritma secara luwes, efisien dan tepat dalam pemecahan masalah; b) menggunakan penalaran pada pola dan sifat, melakukan manipulasi matematika dalam membuat generalisasi, menyusun bukti atau menjelaskan gagasan dan pernyataan matematika; c) memecahkan masalah yang meliputi kemampuan memahami masalah, merancang model matematika, menyelesaikan model dan menafsirkan solusi yang diperoleh; d) mengomunikasikan gagasan dengan symbol, tabel, diagram, atau media lain untuk memperjelas keadaan atau masalah; dan e) memiliki sikap menghargai kegunaan matematika dalam kehidupan, yaitu memiliki rasa ingin tahu, perhatian dan minat dalam mempelajari matematika serta sikap ulet dan percaya diri dalam pemecahan masalah (Depdiknas, 2006: 346).

Permasalahan dalam kehidupan sehari-hari yang terkait dengan matematika biasanya dituangkan dalam soal cerita. Pemberian soal cerita dimaksudkan untuk mengenalkan kepada siswa tentang manfaat matematika dalam kehidupan sehari-hari dan untuk melatih kemampuan siswa dalam menyelesaikan masalah matematika didalamnya. Berdasarkan hasil wawancara secara tidak terstruktur dengan siswa ketika melaksanakan kegiatan Pengenalan Lingkungan Persekolahan (PLP) di SMP Negeri 1 Kopang, peneliti menemukan banyak siswa yang menganggap mata pelajaran matematika itu pelajaran yang sulit, ribet, tidak menyenangkan dan menakutkan sehingga mengakibatkan banyak siswa tidak memperhatikan ketika dijelaskan dan berdampak pada ketidakmampuan siswa mengerjakan soal latihan yang diberikan terutama dalam bentuk soal cerita. Hal tersebut sesuai dengan hasil wawancara dengan salah seorang guru matematika di SMP Negeri 1 Kopang yang mengatakan bahwa ketika siswa diberikan soal cerita, banyak siswa yang tidak memahami maksud dari soal, tidak mengetahui rumus yang digunakan dan tidak bisa menyelesaikan perhitungan. Pemaparan tersebut diperkuat dengan jawaban siswa dalam menyelesaikan soal cerita matematika materi aritmetika sosial pada Gambar 1 berikut:

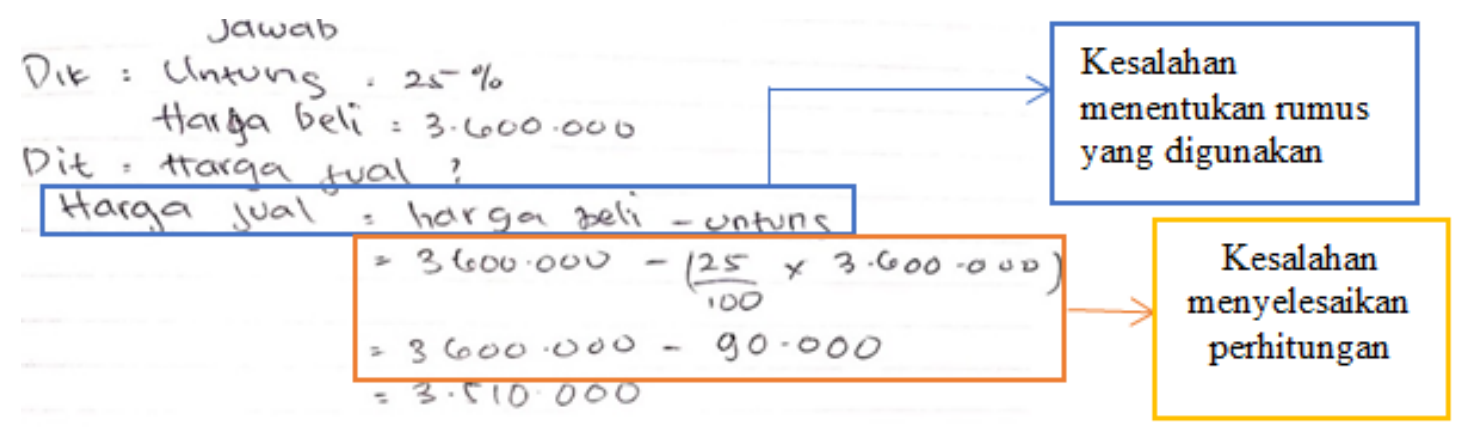

Gambar 1. Contoh Jawaban Siswa Dalam Menyelesaikan Soal Cerita Materi Aritmetika Sosial 
Berdasarkan jawaban siswa tersebut, dapat dilihat bahwa kesalahan siswa terletak pada ketidakmampuan siswa untuk memahami soal (kemampuan pemahaman konsep matematika) dan menyelesaikan perhitungan (kemampuan numerik) dengan baik. Sehingga peneliti ingin mengetahui seberapa besar pengaruh kemampuan pemahaman konsep matematika dan kemampuan numerik terhadap kemampuan siswa dalam menyelesaikan soal cerita matematika. Menyelesaikan soal cerita matematika membutuhkan kemampuan siswa untuk mengubah kalimat yang terdapat dalam soal ke dalam bentuk model matematika terlebih dahulu untuk dilanjutkan ke tahap perhitungan sehingga mendapatkan hasil sesuai dengan permintaan soal.

Rendahnya kemampuan siswa dalam menyelesaikan soal cerita juga ditunjukkan pada hasil ulangan harian materi aritmetika sosial kelas VII A s.d VII F berikut:

\begin{tabular}{cccc}
\hline No. & Kelas & $\begin{array}{c}\text { Persentase Siswa yang Nilainya } \\
\geq \text { KKM (75) }\end{array}$ & $\begin{array}{c}\text { Persentase Siswa yang Nilainya } \\
<\text { KKM (75) }\end{array}$ \\
\hline 1 & Kelas A & $37 \%$ & $63 \%$ \\
\hline 2 & Kelas B & $41 \%$ & $59 \%$ \\
\hline 3 & Kelas C & $28 \%$ & $72 \%$ \\
\hline 4 & Kelas D & $30 \%$ & $70 \%$ \\
\hline 5 & Kelas E & $28 \%$ & $72 \%$ \\
\hline 6 & Kelas F & $28 \%$ & $72 \%$ \\
\hline
\end{tabular}

Tabel 1. Persentase Hasil Ulangan Harian Kelas VII A s.d VII F Materi Aritmetika Sosial Semester Genap Tahun Ajaran 2020/2021

Berdasarkan data di atas, kemampuan siswa dalam menyelesaikan soal cerita matematika dapat dikategorikan rendah karena masih banyak siswa yang nilainya berada di bawah KKM, sehingga pihak sekolah dan guru merasa perlu untuk mengetahui faktor-faktor apa saja yang harus ditekankan dalam upaya meningkatkan kemampuan siswa dalam menyelesaikan soal cerita matematika. Sejalan dengan hasil penelitian Tim Pusat Pengembangan Penataran Guru (PPPG) matematika di beberapa sekolah di Indonesia juga mengungkapkan bahwa siswa mengalami kesulitan dalam menyelesaikan soal-soal yang melibatkan pemecahan masalah dan menerjemahkan soal kehidupan sehari-hari ke model matematika (Danoebroto, 2013: 75).

Menurut Khasanah (2015: 2), soal cerita matematika bertujuan agar siswa berlatih dan berpikir secara deduktif, dapat melihat hubungan dan kegunaan matematika dalam kehidupan seharihari dan dapat menguasai keterampilan matematika serta memperkuat konsep matematika. Pemahaman konsep merupakan hal yang sangat penting dalam pembelajaran matematika, dengan memahami konsep siswa dapat mengembangkan kemampuannya dalam pembelajaran matematika. Semua materi matematika yang ada di sekolah mengandung aspek pemahaman konsep karena memang kemampuan mendasar dalam belajar matematika adalah memahami konsep terlebih dahulu. Pemahaman konsep yang baik akan memberikan kemudahan kepada siswa untuk mengingat, menggunakan dan menyelesaikan berbagai soal yang bervariasi sesuai dengan konsep yang telah dipelajari seperti menyelesaikan soal cerita. Namun, siswa seringkali cenderung menghapalkan 
rumus yang diberikan oleh guru tanpa memahami maksudnya. Begitupula dengan contoh soal yang diberikan. Sehingga, jika siswa dihadapkan pada soal yang berbeda dari contoh yang diberikan, mereka akan mulai kesulitan untuk mengejakannya. Hal ini menunjukkan bahwa siswa tidak mampu memahami konsep yang diberikan (Novitasari, 2017; Novitasari et al., 2021, 2019) Indikator dari kemampuan pemahaman konsep matematika adalah sebagai berikut: a) menyatakan ulang sebuah konsep; b) mengklasifikasikan objek menurut sifat-sifat tertentu; c) memberikan contoh dan bukan contoh dari suatu konsep; d) menyajikan konsep dalam berbagai bentuk representasi matematis; e) mengembangkan syarat perlu dan syarat cukup suatu konsep; f) menggunakan, memanfaatkan dan memilih prosedur atau operasi tertentu; g) mengaplikasikan konsep atau algoritma pemecahan masalah (Moore, 2015: 176).

Selain kemampuan pemahaman konsep, kemampuan numerik juga merupakan kemampuan yang sangat mutlak diperlukan dalam pembelajaran matematika. Hal ini disebabkan karena karakteristik ilmu matematika yang umumnya melibatkan angka, analisis dan perhitungan pasti. Menurut Irawan \& Kencanawaty (2017: 112) kemampuan numerik adalah kemampuan yang dimiliki seseorang untuk menggunakan angka-angka, melakukan perhitungan dan merubah permasalahan uraian cerita menjadi angka-angka yang selanjutnya dapat dilakukan perhitungan dengan matematika. Kemampuan numerik juga sangat penting dalam menyelesaikan soal cerita, karena soal cerita sangat erat hubungannya dengan operasi bilangan. Soal cerita biasanya diwujudkan dalam kalimat yang di dalamnya terdapat persoalan atau permasalahan yang penyelesaiannya menggunakan keterampilan berhitung (Budiyono, 2008: 7). Adapun indikator kemampuan numerik adalah sebagai berikut: a) mampu melakukan operasi penjumlahan; b) mampu melakukan operasi pengurangan; c) mampu melakukan operasi perkalian; d) mampu melakukan operasi pembagian; dan e) mampu melakukan perhitungan aritmatika dasar (Prasetyono, 2010: 85).

Materi pola bilangan merupakan salah satu materi yang diajarkan di Sekolah Menengah Pertama (SMP). Salah satu bentuk penyajian soal pola bilangan ini adalah soal bentuk cerita, karena materi ini erat kaitannya dengan kehidupan sehari-hari. Tahapan-tahapan penyelesaian dari soal cerita menurut Polya (1973: 6-14) yaitu: a) keterampilan memahami masalah (understanding the problem); b) keterampilan merencanakan pemecahan masalah (devising plan); c) keterampilan menjalankan rencana (carrying out the plan); d) keterampilan memeriksa kembali (looking back).

Penelitian terdahulu yang telah dilakukan umumnya meneliti mengenai pengaruh kemampuan verbal dan kemampuan numerik terhadap kemampuan menyelesaikan soal cerita matematika. Salah satunya penelitian yang dilakukan oleh Awaluddin et al., (2019). Namun, penelitian mengenai pengaruh pemahaman konsep matematika dan kemampuan numerik terhadap kemampuan menyelesaikan soal cerita belum banyak dilakukan. Berdasarkan uraian di atas, maka tujuan penelitian ini adalah untuk mengetahui pengaruh kemampuan pemahaman konsep matematika dan kemampuan numerik terhadap kemampuan menyelesaikan soal cerita baik secara parsial maupun simultan. 


\section{METODE}

Jenis penelitian yang digunakan adalah ex-post facto dengan pendekatan kuantitatif yang bertujuan untuk mengetahui pengaruh kemampuan pemahaman konsep matematika dan kemampuan numerik terhadap kemampuan menyelesaikan soal cerita matematika baik secara parsial maupun simultan. Penelitian ini dilakukan di SMP Negeri 1 Kopang. Populasi dalam penelitian ini adalah siswa kelas VIII SMP Negeri 1 Kopang tahun ajaran 2021/2022 sebanyak 177 siswa. Jumlah sampel sebanyak 36 siswa yang diambil dengan teknik simple random sampling.

Teknik pengumpulan data yang digunakan berupa tes yang berbentuk pilihan ganda untuk memperoleh data kemampuan pemahaman konsep matematika dan kemampuan numerik yang masing-masing tes terdiri dari 20 soal dengan jawaban benar diberi skor 1 dan salah diberi skor 0 . Sedangkan, tes berbentuk uraian digunakan untuk memperoleh data kemampuan menyelesaikan soal cerita matematika yang terdiri dari 4 buah soal. Kriteri penskoran untuk masing-masing tes adalah sebagai berikut:

\begin{tabular}{clc}
\hline No. & \multicolumn{1}{c}{ Indikator } & Skor \\
\hline 1. & Mampu menentukan hal yang diketahui & 3 \\
\hline 2. & Mampu menentukan hal yang ditanyakan & 3 \\
\hline 3. & Mampu membuat model matematika & 3 \\
\hline 4. & Mampu melakukan perhitunga & 5 \\
\hline 5. & Mampu menuliskan jawaban akhir sesuai permintaan soal & 3 \\
\hline
\end{tabular}

Tabel 2. Cara Penskoran Tes Berbentuk Uraian

Penentuan nilai akhir:

$$
\text { Nilai }=\frac{\text { Jumlah skor yang diperoleh }}{\text { Jumlah skor maksimal }} \times 100
$$

Adapun untuk mengetahui tingkatan kemampuan siswa dalam masing-masing variabel, maka digunakan interval nilai dan predikatnya sebagai berikut (Muhammad, 2017: 21) :

\begin{tabular}{ccc}
\hline Interval & Predikat & Keterangan \\
\hline $93-100$ & A & Sangat Baik \\
\hline $84-92$ & B & Baik \\
\hline $75-83$ & C & Cukup \\
\hline$<75$ & D & Kurang \\
\hline
\end{tabular}

Tabel 3. Interval Nilai dan Predikat Untuk KKM 75

Data yang diperoleh dianalisis menggunakan analisis uji prayarat yaitu uji normalitas, uji linieritas, uji multikolinieritas dan uji heteroskedastisitas kemudian dilanjutkan dengan uji hipotesis yaitu analisis regresi linier sederhana dan berganda. Data dalam penelitian ini juga di uji dengan uji t dan uji $\mathrm{F}$ untuk mengetahui tingkat signifikansi pengaruh antara variabel bebas dengan variabel terikat secara parsial dan simultan. Sedangkan untuk mengetahui tingkat hubungan antara variabel bebas 
dengan variabel bebas digunakan uji korelasi (r), kemudian dilanjutkan dengan uji koefisien determinasi $(\mathrm{Kd})$ untuk mengetahui seberapa persen $(\%)$ besar pengaruh variabel bebas terhadap variabel terikat secara parsial maupun simultan.

\section{HASIL DAN PEMBAHASAN}

\section{Hasil Penelitian}

\section{a. Data Hasil Penelitian}

Kategori nilai kemampuan siswa yang diperoleh pada masing-masing variabel adalah sebagai berikut:

\begin{tabular}{ccccc}
\hline \multirow{2}{*}{ Variabel } & \multicolumn{4}{c}{ Jumlah Siswa (\%) } \\
\cline { 2 - 5 } & Sangat Baik & Baik & Cukup & Kurang \\
\hline KPKM & $0(0 \%)$ & $0(0 \%)$ & $2(5,56 \%)$ & $34(94,44 \%)$ \\
\hline KN & $0(0 \%)$ & $0(0 \%)$ & $1(2,78 \%)$ & $35(97,22 \%)$ \\
\hline KMSC & $0(0 \%)$ & $1(2,78 \%)$ & $0(0 \%)$ & $35(97,22 \%)$ \\
\hline
\end{tabular}

Tabel 4. Kategori Kemampuan Pemahaman Konsep Matematika (KPKM), Kemampuan Numerik (KN) dan Kemampuan Menyelesaikan Soal Cerita (KMSC)

Berdasarkan Tabel 4. dapat dilihat bahwa kategori kemampuan pemahaman konsep matematika siswa secara umum berada dalam kategori kurang yaitu sebesar 94,44\% dan tidak ada siswa yang berada pada kategori baik dan sangat baik. Begitupula pada kemampuan numerik, tidak ada siswa yang memenuhi kategori baik dan sangat baik. Kemudian pada kemampuan menyelesaikan soal cerita matematika, tidak ada siswa yang memenuhi kategori cukup dan sangat baik. Kemampuan numerik dan kemampuan siswa dalam menyelesaikan soal cerita matematika secara umum berada pada kategori kurang yaitu sebesar 97,22\%.

\section{b. Analisis Data}

Hasil perhitungan analisis regresi linier sederhana, regresi linier berganda dan koefisien determinasi kemampuan pemahaman konsep matematika dan kemampuan numerik terhadap kemampuan menyelesaikan soal cerita dapat dilihat pada Tabel 6. berikut:

\begin{tabular}{ccccc}
\hline Variabel bebas & Constant & Koefisien & $\mathrm{R}$ & R Square \\
\hline $\begin{array}{c}\text { Kemampuan Pemahaman } \\
\text { Konsep Matematika }\end{array}$ & 14,573 & 0,708 & 0,844 & 0,712 \\
\hline Kemampuan Numerik & 8,099 & 0,815 & 0,726 & 0,526 \\
\hline Kemampuan Pemahaman & 5,714 & 0,546 dan & 0,869 & 0,756 \\
Konsep Matematika dan & & 0,319 & & \\
Kemampuan Numerik & & & & \\
\hline
\end{tabular}

Tabel 5. Hasil Analisis Data Uji Regresi Linier 
Berdasarkan Tabel 5, diperoleh persamaan regresi sederhana kemampuan pemahaman konsep matematika sebagai berikut: $Y=14,573+0,708 X_{1}$. Koefisien regresi variabel kemampuan pemahaman konsep matematika $\left(X_{1}\right)$ sebesar 0,708 bertanda positif, maka dapat diartikan bahwa kemampuan pemahaman konsep matematika berpengaruh positif terhadap kemampuan menyelesaikan soal cerita. Pada Tabel 6 juga dapat dilihat bahwa nilai koefisien korelasinya $(R)$ sebesar 0,844 , artinya hubungan antara kemampuan pemahaman konsep matematika dengan kemampuan siswa dalam menyelesaikan soal cerita termasuk dalam kategori sangat kuat dan nilai koefisien determinasi ( $R$ square) sebesar 0,712 , berarti dapat disimpulkan bahwa sebesar 71,2\% kemampuan siswa dalam menyelesaikan soal cerita ditentukan oleh kemampuan pemahaman konsep matematika.

Berdasarkan Tabel 5 diperoleh persamaan regresi sederhana kemampuan numerik sebagai berikut: $Y=8,099+0,815 X_{2}$. Koefisien regresi variabel kemampuan numerik $\left(X_{2}\right)$ sebesar 0,815 bertanda positif, maka dapat diartikan bahwa kemampuan numerik berpengaruh positif terhadap kemampuan menyelesaikan soal cerita. Pada Tabel 6 juga dapat dilihat bahwa nilai koefisien korelasinya $(R)$ sebesar 0,726 , artinya hubungan antara kemampuan numerik dengan kemampuan siswa dalam menyelesaikan soal cerita termasuk dalam kategori kuat dan nilai koefisien determinasi ( $R$ square) sebesar 0,526 berarti dapat disimpulkan bahwa sebesar 52,6\% kemampuan siswa dalam menyelesaikan soal cerita ditentukan oleh kemampuan numerik.

Berdasarkan Tabel 6 diperolah persamaan regresi ganda sebagai berikut: $Y=5,714+$ $0,546 X_{1}+0,319 X_{2}$. Pada Tabel 5 juga diperoleh koefisien korelasinya $(R)$ sebesar 0,869 , artinya hubungan antara kemampuan pemahaman konsep matematika dan kemampuan numerik dengan kemampuan siswa dalam menyelesaikan soal cerita termasuk dalam kategori sangat kuat dan nilai koefisien determinasi ( $R$ square) sebesar 0,756 berarti dapat disimpulkan bahwa sebesar 75,6\% kemampuan siswa dalam menyelesaikan soal cerita matematika ditentukan oleh kemampuan pemahaman konsep dan kemampuan numerik secara bersama-sama.

\section{Pembahasan}

Penelitian ini bertujuan untuk mengetahui pengaruh kemampuan pemahaman konsep matematika dan kemampuan numerik terhadap kemampuan menyelesaikan soal cerita matematika materi pola bilangan kelas VIII SMP Negeri 1 Kopang tahun ajaran 2021/2022 baik secara parsial maupun simultan.

1. Pengaruh Kemampuan Pemahaman Konsep Matematika terhadap Kemampuan Menyelesaikan Soal Cerita

Data hasil penelitian menunjukkan bahwa kategori nilai kemampuan pemahaman konsep matematika siswa yang diperoleh secara umum berada dalam kategori kurang yaitu sebesar 94,44\% dan tidak ada siswa yang berada pada kategori baik dan sangat baik. Skor minimum (terendah) yang diperoleh siswa sebesar 20 dan skor maksimum (tertinggi) sebesar 80. Berdasarkan jawaban siswa 
diperoleh hasil bahwa semakin baik kemampuan pemahaman konsep matematika siswa maka semakin baik pula kemampuan siswa dalam menyelesaikan soal cerita, begitupun sebaliknya.

Hasil analisis regresi linier sederhana kemampuan pemahaman konsep matematika terhadap kemampuan menyelesaikan soal cerita menunjukkan $t_{\text {hitung }}(9,171)>t_{\text {tabel }}(2,034)$. Artinya, terdapat pengaruh yang signifikan kemampuan pemahaman konsep matematika terhadap kemampuan menyelesaikan soal cerita matematika. Besar pengaruh tersebut dapat ditulis dalam bentuk persamaan regresi linier sederhana $Y=14,573+0,708 X_{1}$. Berdasarkan persamaan tersebut dapat dilihat nilai koefisien regresi variabel kemampuan pemahaman konsep matematika $\left(X_{1}\right)$ sebesar 0,708 bertanda positif. Maka dapat diartikan bahwa kemampuan pemahaman konsep matematika berpengaruh positif terhadap kemampuan menyelesaikan soal cerita matematika. Adapun tingkat hubungan antara kemampuan pemahaman konsep matematika dengan kemampuan siswa dalam menyelesaikan soal cerita berada dalam kategori sangat kuat karena diperoleh koefisien korelasinya sebesar 0,844 . Kemudian diperoleh juga $R$ square sebesar 0,712 , artinya persentase kontribusi pengaruh kemampuan pemahaman konsep matematika terhadap kemampuan menyelesaikan soal cerita sebesar $71,2 \%$ dan sisanya dipengaruhi oleh variabel lain. Tall \& Razali (1993: 209) menyatakan bahwa kesalahan yang banyak dialami siswa dalam mengerjakan soal cerita matematika adalah kesalahan konsep dan pemahaman dalam belajar. Hasil penelitian ini sejalan dengan penelitian Nurfarikhin (2010: 106) bahwa terdapat hubungan positif antara kemampuan pemahaman konsep dengan kemampuan pemecahan masalah matematika. Sehingga, berdasarkan pendapat dan hasil analisis data dapat disimpulkan bahwa kemampuan pemahaman konsep matematika memiliki pengaruh positif yang signifikan terhadap kemampuan menyelesaikan soal cerita.

2. Pengaruh Kemampuan Numerik terhadap Kemampuan Menyelesaikan Soal Cerita

Data hasil penelitian menunjukkan bahwa kategori nilai kemampuan numerik secara umum berada dalam kategori kurang yaitu sebesar $97,22 \%$ dan tidak ada siswa yang berada pada kategori baik dan sangat baik. Skor minimum (terendah) yang diperoleh siswa sebesar 35 dan skor maksimum (tertinggi) sebesar 80. Berdasarkan jawaban siswa diperoleh hasil bahwa semakin baik kemampuan numerik siswa maka semakin baik pula kemampuan siswa dalam menyelesaikan soal cerita matematika, begitupun sebaliknya.

Uji analisis regresi linier sederhana kemampuan numerik terhadap kemampuan menyelesaikan soal cerita matematika menunjukkan $t_{\text {hitung }}(6,148)>t_{\text {tabel }}(2,034)$. Artinya, terdapat pengaruh yang signifikan kemampuan numerik terhadap kemampuan menyelesaikan soal cerita. Besar pengaruh tersebut dapat ditulis dalam bentuk persamaan regresi linier sederhana $\mathrm{Y}=$ $8,099+0,815 X_{2}$. Berdasarkan persamaan tersebut dapat dilihat nilai koefisien regresi variabel kemampuan numerik $\left(X_{2}\right)$ sebesar 0,815 bertanda positif. Maka dapat diartikan bahwa kemampuan numerik berpengaruh positif terhadap kemampuan menyelesaikan soal cerita. Adapun tingkat hubungan antara kemampuan numerik dengan kemampuan siswa dalam menyelesaikan soal cerita 
matematika berada dalam kategori kuat karena diperoleh koefisien korelasinya sebesar 0,726. Kemudian diperoleh juga $R$ square sebesar 0,526, artinya persentase kontribusi pengaruh kemampuan numerik terhadap kemampuan menyelesaikan soal cerita sebesar 52,6\% dan sisanya dipengaruhi oleh variabel lain. Rahardjo \& Waluyati (2011: 8) menyatakan bahwa soal cerita matematika adalah soalsoal yang terkait dengan kehidupan sehari-hari untuk dicari penyelesaiannya menggunakan kalimat matematika yang memuat bilangan, operasi hitung $(+,-, \times,:)$ dan relasi $(=,<,>, \leq, \geq)$ sehingga kemampuan numerik dibutuhkan dalam proses penyelesaiannya. Hasil penelitian ini sejalan dengan penelitian Awaluddin et al., (2019: 3) bahwa terdapat pengaruh yang signifikan antara kemampuan numerik terhadap kemampuan menyelesaikan soal cerita siswa. Sehingga, berdasarkan pendapatpendapat dan hasil analisis data dapat disimpulkan bahwa kemampuan numerik memiliki pengaruh positif yang signifikan terhadap kemampuan siswa dalam menyelesaikan soal cerita.

3. Pengaruh Kemampuan Pemahaman Konsep Matematika dan Kemampuan Numerik terhadap Kemampuan Menyelesaikan Soal Cerita

Selanjutnya, data hasil penelitian menunjukkan bahwa kategori nilai kemampuan menyelesaikan soal cerita yang diperoleh secara umum berada dalam kategori kurang yaitu sebesar 97,22\% dan tidak ada siswa yang berada pada kategori cukup dan sangat baik. Skor minimum (terendah) yang diperoleh siswa sebesar 35 dan skor maksimum (tertinggi) sebesar 84. Berdasarkan jawaban siswa diperoleh hasil bahwa semakin baik kemampuan pemahaman konsep matematika dan kemampuan numerik siswa maka semakin baik pula kemampuan siswa dalam menyelesaikan soal cerita matematika, begitupun sebaliknya.

Uji analisis regresi linier berganda kemampuan pemahaman konsep matematika dan kemampuan numerik terhadap kemampuan menyelesaikan soal cerita diperoleh $F_{\text {hitung }}(51,020)>$ $F_{\text {tabel }}(3,28)$. Hal ini menunjukkan bahwa terdapat pengaruh yang signifikan kemampuan pemahaman konsep matematika dan kemampuan numerik secara bersama-sama terhadap kemampuan menyelesaikan soal cerita. Besar pengaruh tersebut dapat ditulis dalam bentuk persamaan regresi linier berganda $Y=5,714+0,546 X_{1}+0,319 X_{2}$. Adapun tingkat hubungan antara kemampuan pemahaman konsep matematika dan kemampuan numerik dengan kemampuan siswa dalam menyelesaikan soal cerita berada dalam kategori sangat kuat karena diperoleh koefisien korelasinya sebesar 0,869. Kemudian diperoleh juga $R$ square sebesar 0,756 , artinya persentase kontribusi pengaruh kemampuan pemahaman konsep matematika dan kemampuan numerik secara bersamasama terhadap kemampuan menyelesaikan soal cerita sebesar 75,6\% dan sisanya dipengaruhi oleh variabel lain. Mardjuki (1999: 4) mengemukakan bahwa salah satu kemampuan yang diperlukan untuk menyelesaikan soal cerita adalah kemampuan melakukan pengerjaan hitung seperti penjumlahan, pengurangan, perkalian dan pembagian yang termasuk dalam kemampuan numerik. Berdasarkan pendapat dan analisis data di atas, dapat disimpulkan bahwa kemampuan pemahaman 
konsep matematika dan kemampuan numerik memiliki pengaruh positif yang signifikan secara bersama-sama terhadap kemampuan siswa dalam menyelesaikan soal cerita.

\section{KESIMPULAN}

Berdasarkan hasil penelitian, maka dapat ditarik kesimpulan sebagai berikut:

a. Kemampuan pemahaman konsep matematika memberikan pengaruh positif yang signifikan terhadap kemampuan menyelesaikan soal cerita materi pola bilangan kelas VIII SMP Negeri 1 Kopang tahun ajaran 2021/2022 dengan kontribusi sebesar 71,2\%.

b. Kemampuan numerik memberikan pengaruh positif yang signifikan terhadap kemampuan menyelesaikan soal cerita materi pola bilangan kelas VIII SMP Negeri 1 Kopang tahun ajaran 2021/2022 dengan kontribusi sebesar 52,6\%.

c. Kemampuan pemahaman konsep matematika dan kemampuan numerik secara bersama-sama memberikan pengaruh positif yang signifikan terhadap kemampuan menyelesaikan soal cerita materi pola bilangan kelas VIII SMP Negeri 1 Kopang tahun ajaran 2021/2022 dengan kontribusi sebesar $75,6 \%$.

Berdasarkan hasil penelitian, nilai kemampuan pemahaman konsep matematika, kemampuan numerik dan kemampuan menyelesaikan soal cerita yang diperoleh siswa umumnya berada dalam kategori kurang. Guru sebaiknya menerapkan strategi pembelajaran yang dapat melatih kemampuan pemahaman konsep matematika dan kemampuan numerik siswa sehingga kategori nilai kemampuan siswa dalam menyelesaikan soal cerita tidak hanya berada dalam kategori kurang.Untuk meningkatkan penguasaan rumus, siswa hendaknya lebih ditekankan untuk memahami rumus yang ada, salah satunya dengan cara memberikan langkah-langkah untuk mendapatkan rumus, bukan hanya untuk menghafalnya.

\section{DAFTAR PUSTAKA}

Awaluddin, W., Prayitno, S., \& Suryadi, R. (2019). Pengaruh Kemampuan Verbal dan Kemampuan Numerik terhadap Kemampuan Menyelesaikan Soal Cerita Matematika Siswa Kelas IX SMPN 11 mataram Tahun Pelajaran 2018/2019. 1-4.

Budiyono. (2008). Kesalahan Mengerjakan Soal Cerita Dalam Pembelajaran Matematika. Solo: Cendikia.

Danoebroto, S. W. (2013). Meningkatkan Kemampuan Pemecahan Masalah Melalui Pendekatan Pmri Dan Pelatihan Metakognitif. Jurnal Penelitian Dan Evaluasi Pendidikan, 11(1), 73-87. https://doi.org/10.21831/pep.v11i1.1419

Depdiknas. (2006). Permendiknas No.22 Tahun 2006 tentang Standar Isi untuk Satuan Pendidikan Dasar dan Menengah. Jakarta: Depdiknas. 
Irawan, A., \& Kencanawaty, G. (2017). Peranan Kemampuan Verbal Dan Kemampuan Numerik Terhadap Kemampuan Berpikir Kritis Matematika. AKSIOMA Journal of Mathematics Education, 5(2), 110-119. https://doi.org/10.24127/ajpm.v5i2.669

Khasanah, U. (2015). Kesulitan Menyelesaikan Soal Cerita Matematika Pada Siswa SMP. Publikasi Ilmiah, 13(3), 1-14.

Mardjuki. (1999). Pembelajaran Soal Cerita dalam Matematika. Laporan Penelitian. Yogyakarta: FMIPA UNY.

Moore, K. D. (2015). Effective Instructional Strategies: From Theory to Practice. Singapore: SAGE Publication.

Muhammad, H. (2017). Panduan Penilaian oleh Pendidik dan Satuan Pendidikan Sekolah Menengah Pertama. Jakarta: Kementerian pendidikan dan Kebudayaan.

Novitasari, D. (2017). Analisis Kreativitas Siswa Dalam Pemecahan Masalah Visual Spasial Dan Logis Matematis Ditinjau Dari Gender. Jurnal Media Pendidikan Matematika, 5(2), 75. https://doi.org/10.33394/mpm.v5i2.1837

Novitasari, D., Hamdani, D., Arifin, S., \& Junaidi. (2021). Pengembangan lkpd berbasis geogebra untuk meningkatkan pemahaman konsep matematika. Jurnal Edukasi Dan Sains Matematika, 7(1), 1-16. https://doi.org/doi.org/10.25134/jes-mat.v7i1.3916

Novitasari, D., Indrawati, \& Risfianty, D. K. (2019). Penerapan Pendekatan Saintifik Berbasis Geogebra dalam Pembelajaran Matematika. PRISMA, Prosiding Seminar Nasional Matematika, 2, 178-184. https://journal.unnes.ac.id/sju/index.php/prisma/article/view/28908

Nurfarikhin, F. (2010). Hubungan Kemampuan Pemahaman Konsep dan Kemampuan Penalaran dengan Kemampuan Pemecahan Masalah Pada Materi Bangun Ruang Sisi Lengkung. E-DuMath, 2(2).

Polya. (1973). How To Solve It. A New Aspect of Mathematical Method. New Jersey: Princeton University Press.

Prasetyono, D. S. (2010). Edisi Lengkap Tes IQ dan SQ. Yogyakarta: Flash Book.

Rahardjo, M., \& Waluyati, A. (2011). Pembelajaran Soal Cerita Operasi Hitung Campur Di Sekolah Dasar. Yogyakarta: Pustaka Pengembangan Dan Pemberdaya Pendidikan Dan Tenaga Kependidikan Matematika.

Tall, D., \& Razali, M. R. (1993). Diagnosing Students 'Difficulties in Learning Mathematics. https://doi.org/10.1080/0020739930240206

How to cite : Hartini, Z., Azmi, S., Novitasari, D., \& Kurniati, N., 2022. Pengaruh Kemampuan Pemahaman Konsep Matematika dan Kemampuan Numerik Terhadap Kemampuan Menyelesaikan Soal Cerita. Jurnal Riset Pendidikan Matematika Jakarta. 4(1). 11-22. https://doi.org/10.21009/jrpmj.v4i1.23022

To link to this article: https://doi.org/10.21009/jrpmj.v4i1.23022 